\title{
THE MOST FUNDAMENTAL PROBLEMS AFFLICTING THE MULTILATERAL TRADE REGIME AND HOW THEY MIGHT BE RESOLVED
}

\author{
Georgia Giannakarou \\ University of Cambridge, Greece
}

\begin{abstract}
In this essay, I deal with the most fundamental problems and challenges afflicting the multilateral regime currently. Discussing whether, and to what extent, the WTO crisis is self-inflicted, or totally external, or, better, a mixed one, I argue that there are three main types of WTO problems, (a) existential, (b) procedural or functional and (c) external or trade-related ones, and shedding light onto previous recommendations and sometimes building on them, I come up with some suggestions as possible solutions to these problems.
\end{abstract}

Keywords: multilateral trade regime, current challenges, existential problems, procedural or functional problems, external or trade-related problems

DOI: http://dx.doi.org/10.15549/jeecar.v1i2.75

\section{INTRODUCTION}

As When the World Trade Organization (WTO) was established in 1995 succeeding the General Agreement on Tariffs and Trade (GATT), it came with a view to both effectively confronting the GATT problems and adapting to a more interconnected and globalized world economy. The Organization's twin foci would be the crowning of post-war efforts for the creation of a functioning organization to deal with the world trade problems in the area of goods, services and intellectual property within the Breton Woods concept. According to both the WTO Agreement (Article III, paragraph 5) and Balaam and Veseth (2008, p. 101), the enlarged and upgraded WTO, would overcome the almost forty-year-old GATT problems, and would cooperate with the International Monetary Fund (IMF) and the World Bank for sustainable development and world well-being. In the broader spectrum of economic and socio-political interconnectedness within a globalized world, away from controversies stemming from the obsolete North-South divide, through trade and regular communication the WTO has been aiming at overall economic growth and world development.

Thus, nineteen years after its creation, there is ongoing contradiction about the role and the function of the WTO in the technologically advanced twenty-first century. The younger member of the Breton Woods organizations is often on the spotlight, albeit with criticism, discontent and outrage. There have been protests, mainly by antiglobalists, during the 1999 Seattle and 2003 Cancun ministerial conferences. The latter failed to bring an agreement among the WTO members and conclude the current -since 2001- and unconcluded Doha Round. Undoubtedly, there have been significant developments that the WTO has brought about. With its 'near-universal membership', according to the Warwick Report (2006, p. 8), -159 members on 2 March 2013 - the average income is on the increase globally (except for some areas in the SubSaharan region), poverty has been decreasing worldwide, labor standards have been improved and women's social status has risen. Nevertheless, there is a prevalent, persistent lack of agreement on certain areas (agriculture and environment included) among its members (Evans and Newnham 1998, p. 580), and new challenges as China, India, Brazil, and Mexico have emerged as major economic powers.

This essay, taking into consideration the latest academic discourse on WTO character, role and functions, is aiming at presenting the most notable challenges the WTO is currently facing. Distinguishing among three main types of WTO problems, existential, procedural or functional and external or trade-related ones, this essay will discuss if, and to what extent the WTO crisis is selfinflicted, or totally external, or, more logically, a mixed one. Shedding light onto previous recommendations and sometimes building on them, the essay will conclude with some suggestions-possible solutions to the WTO problems.

\section{EXISTENTIAL PROBLEMS}

\section{Democratic deficit, fairness, openness and world governance}

Like other international organizations, the WTO also faces the problem of how democratic in its decisionmaking and negotiation processes is. Debates on the socalled democratic deficit of the international organizations abound among theoreticians since the 1990s. Although there are some clear-cut opinions, such as Dahl's 
supporting that 'democracy is unattainable in international organizations', meaning that decision-making in them cannot be democratic because of the enormous heterogeneity of the peoples' interests, the lack of a hypothetical international demos and the absence of a strong common identity (Dahl, 1999), there are concomitantly those who believe in the democratic character of international organizations, or more accurately, in their democratization (Archibugi and Held, 1995). Even though Dahl (1999) characterizes the international organizations as merely undemocratic 'bureaucratic bargaining systems' (p. 33), improvements in the WTO decision-making and negotiation processes have been made.

According to the WTO Agreement (Article III, paragraph 2), the WTO is an international 'rules-based, member-driven organization' providing both a forum for trade negotiations and a framework for the implementation of such negotiations among its members. For equality reasons, decisions are based on the "one-member-onevote" principle, are reached through consensus, and openness and transparency with regard to both its decisionmaking process and to the outside world have improved in comparison with the GATT "Green-Room" era. Nowadays the WTO provides an open website of its official documents, activities, research programs and articles aiming at promoting both awareness and debate; it organizes an annual public symposium and has launched a program of cooperation with parliamentarians for the quick ratification of its agreements, 'a key interface between the WTO and civil society' as Panitchpakdi (2006) has put it (p. 10). Consequently, the WTO is as democratic as it can be, given that it is participatory, representative and cooperative, as democracies have historically been (Schmitter and Karl, 1991, p. 79). Thus, one could argue that the problem with the WTO lays in its accountability, especially pertaining to answering the question 'to whom is the WTO accountable to?'. Supposing the WTO is a democratic organization, the answer would be 'to its constituent members'. Furthermore, according to the WTO Agreement (p. 13), the WTO has a legal personality and does have democratic checks and balances to some extent I refer to the Dispute Settlement Mechanism (DSM) in the broader framework of Dispute Settlement Understanding (DSU), and the Trade Policy Review Mechanism (TPRM). Theoretically everything can be brought under negotiation, governance and WTO organs' accountability included. So, all members' active and critical participation in WTO affairs is the key answer.

Regarding the accusations of hypocrisy, double standards, and unfair trade, more prevalent during the 1990 's and made particularly by the World Bank and by respectable non-governmental organizations (NGOs) such as Oxfam, the almost-universal appeal of the WTO has rendered them mere allegations, or as Bhagwati (2004) has put it, 'little more than rubbish' (p. 5). Furthermore, nondiscrimination, apart from a declared principle, is an accomplished tactic, reinforced by the Most Favored Nation (MFN) principle. Ravenhill (2008) refers to the MFN principle twin foci, which is founding nondiscrimination and depoliticizing trade relations (p. 11). Finally, bearing in mind that even democracies do have economic instabilities and governance problems, let alone democratic international organizations, we should always recall Schmitter and Karl's (1991) statement that 'governability is a challenge for all regimes, not just democratic ones' (p. 86).

Regarding fairness in the WTO, one should always have in mind that the debate is about a highly contested philosophical notion, difficult to be defined in a material world and always redefined according to the institutional context it is embedded in, institutional structure and participatory processes both considered. Drawing on Franck's conception of fairness as 'a composite of two independent variables: legitimacy and distributive justice', Dr Narlikar's 2006 research has proved that although the GATT and WTO decision-making procedures marginalized the equity-based fairness agenda which the developing countries had initially requested, this agenda can be set and influenced by even the weaker members, depending on the latter's adaptation, learning and reframing-of-the-issue capacity, as well as on their coalition strategies (Narlikar, 2006, p. 1027 quoting Franck in p. 1007).

\section{PROCEDURAL OR FUNCTIONAL PROBLEMS}

\section{Decision making process}

According to its official web site, there are 159 members and 25 observers in the WTO on 03 March 2013. Achieving consensus among 159 members at the negotiation table is not a piece-of-cake accomplishment taking into account the immense diversity of population sizes and corresponding representatives' goals expressing different, and sometimes, contradicting governmental interests within the WTO. For some theorists, here exactly lies the source of the WTO's inconclusiveness. The days of the GATT and early WTO, where consensus was easily reached into the Green Room owing to the small members' turnout and the dominance of the old Quad (EU, USA, Canada and Japan, where decisions were made in 'concentric circles') (Clapp 2003, p. 36; Narlikar 2010, p. 717; Watson 2011, p. 448), have passed, especially after the post-Seattle efforts to combat secrecy and improve transparency in the decision-making process have born fruits: members' turnout and active involvement in the WTO have remarkably ameliorated. Although there is a number of international intergovernmental organizations (IMF, World Bank, UNCTAD-WTO included) granted observer status to WTO bodies in order for agreements to be reached quicker in specific areas of interest, according to the WTO Official Site, consensus still cannot be reached in key areas, such as in agriculture and environment. So transparency and democratic procedures seem like a double-edged sword, and here comes the discourse on 'the establishment of an executive or consultative board of some sort' (Narlikar 2005, p. 124).

Proposals in favor of the board have all stressed its rather strictly consultative role conducive to consensus rather than its decision-making character. The EU has been very pro-board after the Seattle and Cancun failures, Canada has proposed the creation of a UN-SecurityCouncil-like committee and Mexico has put forward the restructure of the Green Room into a 'Glass Room'. In 2000, Schott and Watal proposed an informal steering 
committee and, in 2003, Blackhurst and Hartridge suggested a consultative board, but most developing countries still oppose any consultative-board type solution, as this would advance a weighted voting system to the detriment of the ongoing one-member-one-vote system. Moreover, there are some disadvantages with the consultative-board solution. Even an elegant compromising solution proposed by Vinod Rege regarding the establishment of a provisional Informal Steering Committee meets the standard developing countries' objection (Narlikar 2005, pp. 125-127, 143).

A possible solution to this problem could be the existence of a provisional mechanism, which would be automatically activated after failed consensuses on a specific issue in two consecutive Ministerial Conferences. This mechanism would be on the form of a sub-ministerial conference, consisting only of the disagreeing WTO members on a specific issue, meeting on a monthly basis, and taking place after the failed Ministerial Conference on a tight timetable, according to which disagreeing members have either to conclude or withdraw conflicting subjects from the agenda. The sub-ministerial conference will be supported by the Secretariat. The draft outcome-decision of the sub-ministerial would have to be submitted for final approval to the forthcoming Ministerial Conference, so this mechanism will only have a supportive role in a multilayered decision-building system. In case of another consensus failure in confirming the sub-ministerial outcome within the Ministerial Conference, decision should be finally reached within the latter's authority by majority vote - which is also predicted by the WTO Agreement, Article IX, paragraph 1 - and opposing countries will have to conform to this decision. Only in this way, will agreements be reached within a logic timeframe.

\section{Developing countries and the Doha Development Agenda (DDA)}

Although almost half of the 23 founding members of the GATT were developing countries, they actually remained passive members in the GATT Rounds (Das 2003, p. 16). Developing countries' starting point in active, though marginal, participation in the MTNs can be considered the Tokyo Round (1973-79), where through the United Nations Conference on Trade and Development (UNCTAD), they started voicing their grievances against the global trading System. Through the powerless then in formulating global trade rules and policies UNCTAD, developing economies succeeded in getting Special and Differential Treatment (SDT) in world trade with the addition of Part IV to the Articles of the GATT Agreement. Although through both the SDT and the Generalized System of Preferences (GSP) developing countries could have been benefitted, due to their reluctance or inability to influence the formulation of the rules of the global trading system during the GATT Rounds, they benefitted the less; they could not avert industrial economies from taking trade in textiles and apparel out of the GATT system, even though many developing countries had a comparative advantage in these areas. Trade in agriculture also had systematically been kept out of the GATT authority by the Uruguay Round (1986-1994). By both feeling powerless within a "Rich man club" GATT negotiation system and not exercising full-volume trade, they let the industrial countries benefit in the areas of textiles and apparel by using quotas to restrict imports from their markets. In this sense, they are largely responsible for a world trading system impairing their interests (Srinivasan 2002; Das 2003, pp. 16-18).

Since developing countries compound the majority of the WTO signatories, they should, as a whole, take fuller advantage of the WTO, which came into existence with that specific priority purpose in mind: to help developing countries liberalize their trade and benefit by the integration of their economies into a global economy. Although such an argument had been contested by some developing countries, some other ones have indeed been assisted by the WTO efforts achieving goals that come to challenge the term 'developing countries'. Developing countries nowadays have become quite active and adept in forming coalitions within the WTO MTNs (Barton et al. 2006; Narlikar and Odell 2006). It is true that giving a unique and exact definition of a developing country is extremely difficult, since many prior developing countries have worked economic miracles and have ascended to firstclass world trading and/or economic powers.

Despite arguments that agriculture should be withdrawn from the DDA in order for the almost 13-yearold Doha Round to finally conclude, this would constitute neither a solution nor an innovative or welcomed outcome; on the contrary, it would signify a relapse, and a decade of MTNs lost vainly. Agriculture still remains the most protected area globally, as its domestic support and continual subsidization is being highly practiced by the industrial economies (Evans and Newnham 1998, p. 580; Das 2003, p. 17), but it should not be withdrawn from the DDA. Nor should developing countries respond by either raising trading barriers of their own or delaying their liberalization of unilateral trade. Despite the fact that a small number of developing countries (mostly in SubSaharan Africa) have benefitted from inexpensive and subsidized agricultural products, the majority of developing countries should remain effectively involved in the MTNs. Within the WTO negotiations, a possible solution to Doha recurrent deadlock would come from a mutual compromise: developing countries should consistently and persistently push developed countries for eventual reductions in agricultural subsidies according to their commitments, while they themselves should consent to undertake some environmental-friendly commitments; although it may be the developing countries' time for benefits from a liberalized trade in agriculture, they should also respect the environment protection.

\section{Limitations of the Dispute Settlement Mechanism (DSM)}

The DSM, as part of the Understanding on Rules and Procedures Governing the Settlement of Disputes (DSU), which constitutes Annex 2 of the WTO Agreement, is a stronger, more automatic and more effective dispute settlement apparatus than the GATT one, crucial within the multilateral trading system and conducive to the stability and predictability of the global economy (Narlikar 2005, 
pp. 85, 89; Panitchpakdi 2006, pp. 7, 10). The members of the WTO have agreed in case of a trading dispute to resort to DSM instead of taking unilateral action; therefore, they have to either abide by its rules or face retaliation. With around 400 complaints by 2010 (Warwick Report 2006, p. 32 ), almost the same number of disputes within the 47year-old GATT, 95 panel resorts adopted and 64 reports circulated by the Appellate Body, the WTO DSM is 'the most active international adjudicative mechanism', renowned for its quality legal analysis, professionalism and impartiality (Narlikar 2005, p. 85; Panitchpakdi 2006, pp. 8-9; Warwick Report 2006, p. 32).

Although the DSU is considered as the jewel in WTO crown (Narlikar 2005, p. 85; Warwick Report 2006: 32), and has successfully handled over half of the disputes amicably, there are at least two fundamental problems with the increased legalization according to Narlikar (2005, p. 86), and an inexhaustive list of problematic issues underlined by various commentaries and analyses about the degree of appropriate 'judicial activism' (Warwick Report 2006, p. 32). Regarding the latter, the Warwick Commission (2006) noting that only a few and specific developing countries have turned to the DSU for a number of reasons (p. 33), concentrated only to improving access to the DSU for the poorer and smaller members of the WTO and, taking into consideration prior suggestions in the Sutherland Report, made some interesting recommendations. The most significant of these recommendations addressing the developing countries' reluctance to resort to the DSU for fear of reprisals by their trading partners foresees the establishment of a Dispute Settlement Ombudsman. The Ombudsman will offer informal, non-litigious mediation between the parties involved in the form of consultations at a stage prior to official complaint to the DSU, as well as information for the next stage of DSU, in case the mediation fails (Warwick Report 2006, p. 33-36).

Building on the promising Ombudsman proposal, I propose the Ombudsman to be a permanent, highly confidential body aiming at amicable solutions, independently from the DSU procedures (i.e. official complaints). But in order for the Ombudsman to be effective, a reform in the DSU should emphasize that disputes have to be settled both within the WTO Ministerial Conference and within certain time-limits, as proposed in the decision-making section. As about the recommendation concerning cash/monetary compensation, even at an escalating amount, this should be avoided, as the real educative role of sanctions has to be the changing trading attitudes conducive to smoother trading relations globally. The give-and-take character of the WTO should be kept purely on its members' mutually compromising trading tactics, as this will promote solutions to more focal key areas, irrespectively of the members' financial power. Overall, the DSU, having gained a high degree of compliant behavior by members in respect of findings (Warwick Report 2006, p. 4), being respected by both developed and developing countries and preferred even by countries in preferential agreements (Panitchpakdi 2006, p. 9), needs marginal reform.

\section{Regionalism and Preferential Trade Agreements (PTAs)}

Bilateral and regional agreements of a preferential nature, in the form of both Customs Unions (CUs) and Free Trade Agreements (FTAs), being not a completely new phenomenon (Warwick Report 2006, p. 47) and maybe as the corollary of slow decision-making in the multilateral system, have worryingly proliferated since the beginning of the 1990s. Although some theorists hold them harmless or even beneficial to the trading system, and the case may have been so in the past, there is recent evidence that the nature of contemporary PTAs pose a threat to the multilateral trading regime promoted under the auspices of the WTO. Apart from merely producing a confusing 'spaghetti-bowl' effect, according to Bhagwati (Baldwin 2006b, p. 1451), today's PTAs, either between a great power and other smaller countries (i.e., USA and EU with third parties) known as "hub-and-spoke" agreements or among Asian countries, by being either geographically incontiguous or offering the so-called "WTO-plus" provisions, produce an unnecessary 'plethora of competing and overlapping' norms and regulations conducive to both the impediment of international trade and sometimes the detriment of the poorest and the weakest countries in economic and political aspects. Therefore, PTAs lurking unknown stakes are definitely second-best choice to the WTO multilateral agreements: causing market fragmentation and trade diversion, regionalism on an unfair and unstable basis increase unnecessarily the trading costs and reduce trading opportunities that WTO MFN liberalization and multilateralism promise.

Although the WTO provides rules on regionalism (GATT Article XXIV, the 'Enabling Clause' for goods, and the General Agreement on Trade in Services (GATS) Article V for services; Warwick Report 2006, p. 50), it cannot and should not restrict FTAs, neither should WTO insist in simply enforcing its treaty-based rules. As Baldwin (2006b) has put it, "regionalism is here to stay" (p. 1512); in the same vein, the Warwick Report (2006) approves regionalism (p. 45). But, absence of discipline of WTO rules of origin in goods leads to strict, opaque and illegitimate rules in PTAs (Warwick Report 2006, p. 51). Instead, a modern WTO should take a dual action: a concerted, well-informed action to improve its existing vague, inadequate and ineffective rules on regionalism in order to instill order, stability and coherence to its members, and a further comprehensive, non-litigious, confrontation-free one to "multilateralise' regionalism in an attempt to achieve attainable cooperation in the near future. In this right direction, the WTO has recently launched the new provisional Transparency Mechanism, which should render permanent for better results. Under this Mechanism, WTO members are expected to provide information on signed regional agreements with the WTO Secretariat to prepare a factional presentation of the latter. Only in this respect, will the communication between the two parallel spheres of FTAs regionalism and the WTO multilateralism benefit the entire trading community.

Several reform proposals towards compromising regionalism with multilateralism have been made by the Warwick Commission: one on eliminating discrimination of PTAs is to reduce all MFN tariffs to zero, another that 
the largest trading nations should show leadership and refrain from establishing PTAs among themselves. Regarding the Transparency Mechanism, this should be strengthened with a collective surveillance, as well as a code-of-best-practices building capacity (Warwick Report 2006, pp. 51, 53). Building on this Mechanism, I propose that the WTO Secretariat should keep a record of all agreements and reprimand countries entering new PTAs that might nullify preexisting WTO ones, encouraging them to both realize the benefits coming from the latter and abide by them.

\section{EXTERNAL OR TRADE-RELATED PROBLEMS \\ Global financial crisis}

The global financial recession of 2008-9 has put an extra strain on WTO, as tensions among countries have been intensified. Given the fact that the G20 coalition of developing countries have been elevated to a primary forum for global economic governance, the WTO should promote the re-negotiation of quotas, in order for tensions to be alleviated and trade transaction smoothness to be achieved. The WTO having gained significant experience from handling successfully the 1997-8 Asian economic crisis by absorbing the increased exports from Asia (Panitchpakdi 2006, p. 8), has a good precedent in handling economic crises and optimism should prevail in tackling the global financial recession of 2008, as well. The WTO should intensify its efforts towards global regulation of trade.

\section{Environmental degradation and climate change}

On the road to a more liberal world trade regime, the WTO should take into consideration the environmental aspects of trade agreements in a regular and more consistent way, as the environment is a recently-addressed area (Evans and Newnham 1998, p. 580). Environment is a common public good, owned to everyone and no one in particular, as recent catastrophic effects of climate change owing to environmental degradation indicate in geographical areas around the globe, regardless of their contribution in environmental pollution. In the same vein, there should be a greater sense of conformity in environmental protection rules, a more responsible adherence to prior commitments and an eager adoption of further ones by both developed and developing countries.

\section{CONCLUSION}

Since 1995, when the WTO defined its four main functions in Article III of its establishment Agreement (WTO Agreement, p. 10), there have been torrential changes in the world trade regime. In 2006, the Warwick Commission Report on the multilateral trade regime underlined five central challenges facing the WTO in the twenty-first century: the rise and decline of support for Openness; managing multipolar global economic governance; defining the contested boundaries of the WTO; making the WTO work for all members: justice and fairness issues and development; and, multilateralising Preferential Trade Agreements (pp. 9-11). In 2009/10, Hoekman and Kostecki identified the following challenges: the importance of rapidly rising economic powers from Asia, Latin America and Africa; the growing number turn to regionalism; intensification of trade conflicts; the role of business groups and NGOs in trade policy formation and negotiations; the WTO difficulties of addressing investment, competition and procurement policies; WTO pressures for more leadership within the WTO; and, the reemergence of environment-trade policy issues regarding the global climate change (pp. viii-ix). Furthermore, in the 2011 WTO Public Forum, challenges such as the changing nature of global production structures, the impact of technological evolution on Information Technology (IT) and manufacturing, food security and internet-related issues and trade were brought forward (p. 31).

The WTO is not only an organization for the management of the world trade, solely to the interest of economists and governmental officials; it is rather one for the global governance affecting everyone's life. Through its forum and trading negotiations among almost all nations of the globe, consumers' choices, ethical preferences and cultural habits are brought into light. Even public demonstrations associated with almost every WTO ministerial conference indicate its appeal to the public. Globalized trade, just like economic and technological globalization can coexist with cultural globalization. Altogether, globalization as a phenomenon does have a human face, but as Bhagwati (2004) argues, 'we can make that face yet more agreeable' (p. $x$ ), meaning that there is plentiful room for improvements. The WTO, having accomplished great achievements, should not be abolished. Reforms to this 'medieval' organization, as the prior EU Trade Commissioner and current WTO Director GeneralElect Pascal Lamy has called it (Narlikar 2005, p. 124), even institutional ones, especially in the light of the torrential-speed rise of new economic powers from Asia, Latin America and Africa, should be the wise path leading it to greater effectiveness. As Baldwin (2006a) wisely has argued, the major developed-country trading powers should take into consideration the new bargaining power of the developing countries, while the latter should not hold success to negotiations synonym to 'fairness' in establishing new rules (p. 695). Hoekman and Kostecki $(2009 / 10)$ have also suggested adjustments of the world trading system according to the huge economic expansion of developing countries (p. 3). Narlikar (2005) distinguished institutional reform in three directions responding to the WTO problems of 'how', 'what' and 'who' questions respectively (pp. 122-129). In the same vein, humble suggestions towards institutional reforms of some extent have been made in this essay, which holds that the crisis in the WTO is a mixed one, but manageable through systemic reform.

Globalization and integration of developing economies into a more liberalized, but wisely governed, world trade need not be antithetical, or even, contradicting powers. In the 2009/2010 Human Security Report there has been substantial evidence of the world becoming more peaceful. According to war surveys, wars are becoming extinct: they are less frequent, less bloody, and great wars are rare. The Report provides proof that a 10 percent increase in FDI reduces a nation's chance of international or civil war by about 3 percent, and that globalization reduces the reasons 
of a country might want to fight (p. 52). The Report concludes that "[T] modern economies is through increasing productivity and international trade, not through seizing land and raw materials. In addition, the existence of an open global trading regime means it is nearly always cheaper to buy resources from overseas than to use force to acquire them" (p. 29).

Thus, the land and the whole environment are common goods that need considerate usage and respectful handling in order for them to guarantee life perseverance and human well-being. Although defining the general good in a highly heterogeneous organization like the WTO might be quite difficult (Dahl 1999), nevertheless the land and the environment are undoubtedly the supreme common goods, since their degradation can prove fatal to life. Hoekman and Kostecki (2009/10) correctly determine as public good an open multilateral trading system (p. 3). A modern, functional and effective WTO can and should lead the way for world governance by providing the scientific knowhow, apart from the legal and institutional framework, with a view to buttressing sustainable development, economic growth and environmental viability through a globally regulated commerce.

Finally, if 'democracies have the capacity to modify their rules and institutions in response to changing circumstances' as Schmitter and Karl (1991) have pointed out (p. 87), consequently democratic organizations such as the WTO can adapt their scopes and functions as well. Following the cataclysmic economic changes already apparent in the first decade of the twenty-first century, the WTO must pursue systemic reforms to adapt itself into the new socio-political and economic environment.

\section{REFERENCES}

Agreement establishing the WTO, or WTO Agreement $<$ http://www.wto.org/english/docs_e/legal_e/04-wto.pdf $>$

Balaam, David N., Veseth, Michael (2008), Introduction to International Political Economy, 4th edition, New Jersey: Pearson Education International.

Baldwin, Robert (2006a), "Failure of the WTO Ministerial Conference at Cancun: Reasons and Remedies", The World Economy, 29 (6), May, 677-696.

Baldwin, Robert (2006b), "Multilateralising Regionalism: Spaghetti Bowls as Building Blocs on the Path to Global Free Trade", The World Economy, 1451-1518.

Barton, John, Goldstein, Judith Josling, Timothy and Steinberg, Richard (2006), The Evolution of the Trade Regime: Politics, Law, and Economics of the GATT and the WTO, Princeton: Princeton University Press.

Bhagwati, Jagdish (2004), In Defense of Globalization, Oxford: Oxford University Press.

Clapp, Jennifer (2007), "Developing and the WTO Agriculture Negotiations", CIGI Working paper, No. 6, March 2006, $<$ http://www.cigionline.ca/publications/docs/Develop_W TO_Clapp.pdf $>$

Dahl, Robert A. (1999), “Can international organizations be democratic?" in Ian Shapiro and Casiano Hacker-Cordón (eds.), Democracy's Edges, Cambridge: Cambridge University Press, 19-36.
Das, K. Dilip (2003), “Trade and Global Integration”, CSGR Working Paper No. 120/03, June, Coventry: CSGR, University of Warwick.

Evans and Newnham (1998), The Penguin Dictionary of International Relations, London: Penguin.

Hoekman, Bernard and Kostecki, Michel (2009/10), The Political Economy of the World Trading System: the WTO and Beyond, Oxford: OUP (3rd edition).

Human Security Report 2009/2010: The Causes of Peace and the Shrinking Costs of War, published by the Human Security Report Project (HSRP) $<\mathrm{http}$ ://www.hsrgroup.org/human-securityreports/20092010/overview.aspx>

Narlikar, Amrita (2005), The World Trade Organization: A Very Short Introduction, Oxford: Oxford University Press.

Narlikar, Amrita (2006), "Fairness in International Trade Negotiations: Developing countries in the GATT \& WTO”, The World Economy, 29 (8), August, 1005-1029.

Narlikar, Amrita (2010), "New Powers in the Club: The Challenges of Global Trade Governance", International Affairs, 86: 3, May, 717-728.

Narlikar, Amrita and Odell, S. John (2006), “The strict distributive strategy for a bargaining coalition: the Like Minded Group in the World Trade Organization" in Odell, John (ed.), Negotiating Trade: Developing Countries in the WTO and NAFTA, Cambridge: CUP, 115-144.

Panitchpakdi, Supachai (2006), "The WTO at ten: Building on ten years of achievements" in Sacerdoti, Giorgio, Yanovich, Alan and Bohanes, Jan (eds.), The WTO at ten: The Contribution of the Dispute Settlement System, New York and Cambridge: CUP, 7-12.

Ravenhill, John (2008), The Study of Global Political Economy, 2nd edition, Oxford \& N.Y.: OUP $<$ http://www.oup.com/uk/orc/bin/9780199570812/ravenhi 113e_ch01.pdf $>$

Schmitter, Philippe C. and Karl, Terry Lynn (1991), "What Democracy Is... and Is Not", Journal of Democracy, Volume 2, Number 3, Summer, 75-88.

Srinivasan, T.N. (2002), "Globalization: Is it Good or Bad?", Economic Policy Brief, December 23, Stanford, CA: Stanford Institute for Economic Policy Research.

Warwick Commission Report OR Warwick Report (2006), The Multilateral Trade Regime: Which way forward? $<$ http://www2.warwick.ac.uk/research/warwickcommissi on/report>

Watson, Matthew (2011), "Global trade and finance”, in John Baylis, Steve Smith \& Patricia Owens (eds.), The Globalization of World Politics. An Introduction to International Relations, Oxford-New York: Oxford University Press, 5th edition, 444-457.

WTO MINISTERIAL CONFERENCE, Fourth Session, Doha, 9-14 November 2001, WT/MIN(01)DEC/1, 20 November 2001.

WORLD TRADE ORGANIZATION (2012), WTO Public Forum 2011 Seeking answers to global trade challenges, Geneva: WTO www.wto.org/english/res_e/booksp_e/public_forum11_e. pdf 


\section{ABOUT THE AUTHOR}

Georgia Giannakarou, email: ggiannakarou@yahoo.com

Mrs. Georgia Giannakarou is a Professor of Linguistics and an Internationalist. After her European Civilization Bachelor, she completed two Master Programs obtaining: a MA Degree in European and International Studies at University of Athens (2011), and a Master of Studies (MSt) in International Relations at University of Cambridge (2013). Her latest MSt Thesis under the title "China as a World Superpower and the Respect of Human Rights" focuses on China's dynamics for rising to superpower status, while centering on the civil and political rights condition in China, especially during the last two Presidencies of Hu Jintao and Xi Zinping. 